\title{
Fish Diversity and Water Quality of Ayamaru Lake, West Papua
}

\author{
Taufiq Hidayah ${ }^{1,2^{*}}$, Marson $^{1}$, Muhammad $\mathrm{Ali}^{1}$, Ni Komang Suryati ${ }^{1,2}$, Dina Muthmainnah ${ }^{1,2}$ \\ ${ }^{1}$ Research Institute for Inland Fisheries and Extension - Ministry of Marine Affairs and Fisheries \\ ${ }^{2}$ Inland Fishery Resources Development and Management Department (IFRDMD) - SEAFDEC \\ *Corresponding Author: tfahidayah@yahoo.com
}

Article history

\begin{tabular}{llll} 
Received & Received in revised form & Accepted & Available online \\
16 February 2021 & 20 March 2021 & 29 March 2021 & 31 March 2021 \\
\hline
\end{tabular}

\begin{abstract}
Ayamaru lake is one of the lakes in West Papua categorized as karst lake. It is endowed with fish diversity in various ornamental fish and consumption fish with high economic value. Recently, a number of floating net cages is set up, and before causing serious damage, management for keeping the sustainability of fish resources, especially the endemic species, needs to be proposed. This paper would contribute information on fish diversity and the water quality of Ayamaru Lake. The study was conducted in March, July, and November 2019 at Ayamaru Lake, Maybrat Regency, West Papua Province. The data were collected by conducting direct survey, interviewing the fishers, and the related institution, as well as searching the previous studies. Fish and water samples were taken from five stations. The results showed that 15 freshwater fishes were identified. The capture fisheries were practiced using the environment-friendly fishing gears. The water quality was still quite useful to support fish life. To reduce the threat to the presence of endemic fish in the lake, it needs to regulate the release of introduced species by the community, and control the escaped fish from the culture area.
\end{abstract}

Keywords: Ayamaru Lake, fish diversity, waters quality, West Papua

\begin{abstract}
Abstrak: Danau Ayamaru adalah salah satu danau di Papua Barat yang dikategorikan sebagai danau karst. Memiliki keanekaragaman ikan yang tinggi terdiri dari ikan hias dan ikan konsumsi yang bernilai ekonomi tinggi. Saat ini jumlah keramba jaring apung semakin meningkat, dan sebelum menimbulkan kerusakan yang parah perlu adanya usulan pengelolaan untuk menjaga kelestarian sumberdaya ikan, khususnya spesies endemik. Makalah ini akan memberikan kontribusi informasi tentang keanekaragaman ikan dan kualitas air Danau Ayamaru. Penelitian dilakukan pada bulan Maret, Juli, dan November 2019 di Danau Ayamaru, Kabupaten Maybrat, Provinsi Papua Barat. Pengumpulan data dilakukan dengan survei langsung, wawancara dengan nelayan, dan instansi terkait, serta menelusuri studi sebelumnya. Sampel ikan dan air diambil dari lima stasiun. Hasil penelitian mengidentifikasikan 15 spesies ikan air tawar yang ditemukan selama penelitian. Penangkapan ikan dilakukan dengan alat tangkap yang ramah lingkungan. Kualitas air masih cukup baik untuk menunjang kehidupan ikan. Untuk mengurangi ancaman keberadaan ikan endemik di danau perlu dikeluarkan peraturan untuk jenis ikan yang akan dilepasliarkan oleh masyarakat, dan mengontrol ikan budidaya yang keluar dari karamba apung masuk ke perairan danau.
\end{abstract}

Kata Kunci: Danau Ayamaru, keragaman ikan, kualitas perairan, Papua Barat

\section{Introduction}

More than 840 major lakes and 735 small lakes in estimation spread throughout Indonesia, with a maximum of $500 \mathrm{~km} 3$ of water. Those lakes provide $72 \%$ of Indonesia's total surface water supplies [1]. A lake is an area filled with water, surrounded by land, apart from any river or other outlets, stable relative water body, a closed system, lie on the ground, and generally found in mountainous areas or along with the courses of mature rivers [2]. Indonesia's total lake area is the biggest in Southeast Asia, about 1,800,000 ha which 50,000 ha are artificial lakes, with the number 1,575 big and small lakes [2][3]. In fact, the lakes are multi-purposes, useful to support human beings, such as for agriculture purposes, irrigation, generating the hydroelectric power of domestic water supply, recreational purposes, and playing an important role in fishery activities.

There are five lakes in the Maybrat Regency of West Papua, namely Uter Lake at Aitinyo District, Ayamaru Lake at Ayamaru District, Sembra Lake at Teminabuan District, and both Tanimut Lake and Nawawefom Lake at East Aifat. Those lakes are the primary water sources, besides being a tourist destination. Ayamaru Lake is a karst lake [4], located on geographical position E: 132010'30'- S: 01014'26", at an altitude of 280-435 $\mathrm{m}$ above sea level. The lake surface area is 980 ha, with a $30 \mathrm{~m}$ average depth. Ayamaru Lake is divided into three parts, Yahu (top side), Yate (bottom side), and Ikri (the water catchment area from the river). Six rivers flow into the lake, i.e., Ela River, Ismayi River, Framu River, Mosway River, Tetsayoh River, and Bawi River. 
Ayamaru Lake plays an important role in the socio-economic life of the people who live surrounding the lake, such as the transportation, tourism destination, and fisheries sectors. Ayamaru Lake has traditionally functioned for the people's traffic shipment before the existence of public transportation of bus and airplane to connect the area around the Ayamaru District. As one of the lakes for a tourist attraction, supporting facilities for tourist attractions such as rest areas, fishing areas, and dock have been developed.

This lake is endowed with huge fish diversity in various ornamental fish and consumption fish with high economic value. The ornamental fish are colorful such as reddish, yellow, white head, and black body. Some of the ornamental fish are endemic species. The Boeseman's Rainbowfish (Melanotaenia boesemani Allen \& Cross, 1980), a prevalent ornamental freshwater fish inhabits in Ayamaru Lake [5]. The rainbow fish (Melanotaenia ajamaruensis, $M$. boesemani, and $M$. fasinensis) face significant threats and decrease. The consumption of fish with economic value also varies, such as catfish, tilapia, gourami, and shrimp species (red shrimp, yellow and blue shrimp). In 1996, Ayamaru Lake was recorded as the highest exporter of shrimp and fish, around 150 tons.

Recently, a number of floating net cages is set up and it becomes an interesting business. Before causing serious damage, management for keeping the sustainability of fish resources, especially the endemic species, needs to propose. This paper would contribute information on fish diversity and the water quality of Ayamaru Lake to keep sustainable.

\section{Materials and Methods}

The study was conducted in March, July, and November 2019 at Ayamaru Lake, Maybrat Regency, West Papua Province. The primary data were collected by conducting direct survey and interviewing the fishers. The water samples were taken from five stations (Figure 1).

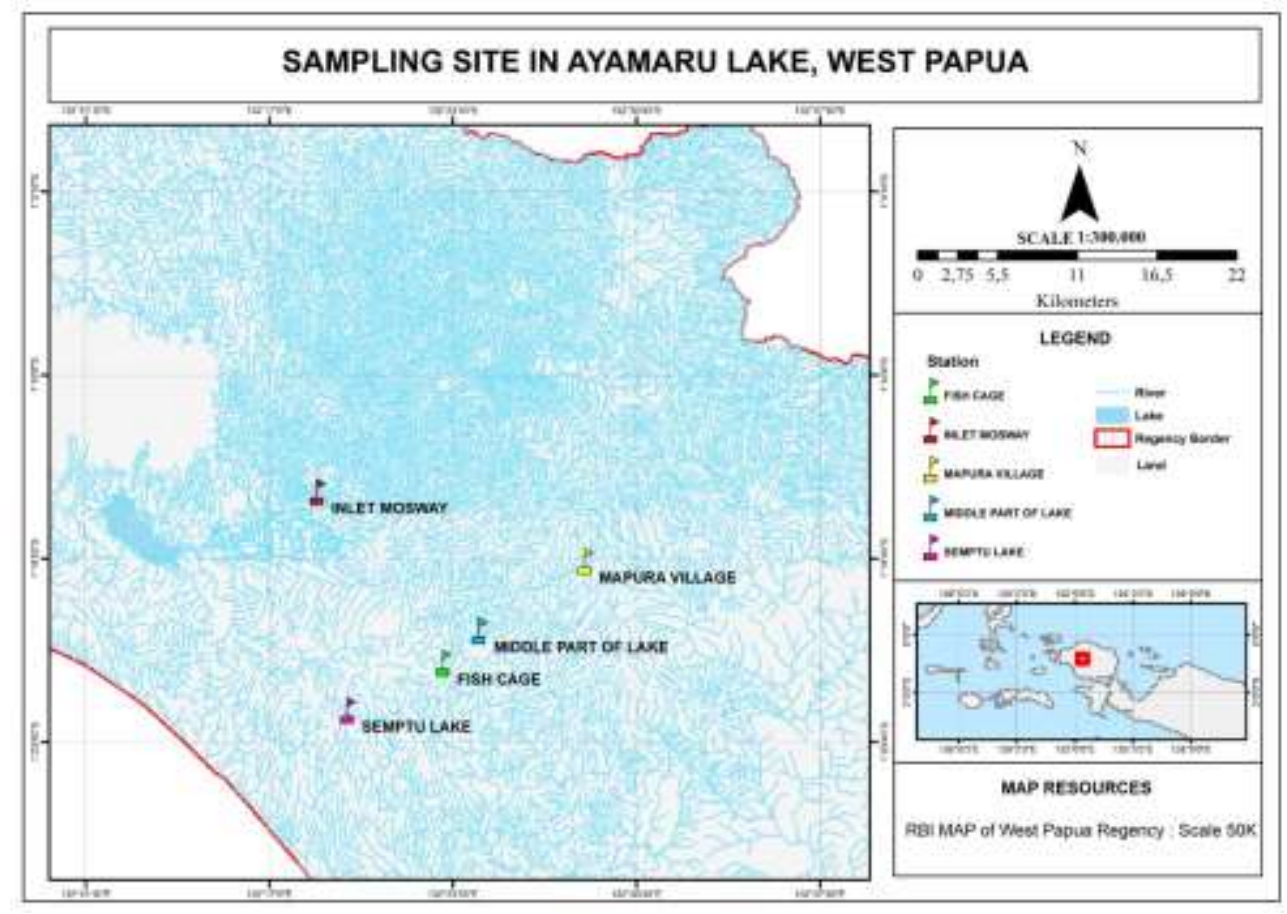

Figure 1: Research site and five stations

Station 1 is the inlet of Ayamaru Lake (Mosway), the largest inlet, and had the most extensive and deepest springs $(11 \mathrm{~m})$ at the upper lake. Station 2 was in the middle part of the lake (Yau Area), which is not too deep, muddy in the bottom (about 2 $\mathrm{m})$ and covered by kumpai grass. Station 3 was in the middle part of the lake (Semptu Area), it is a natural deep pool of fish, rocky in the bottom, and covered by trees. Station 4 is in the lower part of the lake (Mapura Village), which has some water sources, closed to the housing, and surrounding side's agriculture activities. Station 5 has some floating net cages at Yate Area for monitoring the fish culture activity.
The fish diversity was collected from the fishing experimental and fishers caught in all areas of Ayamaru Lake. While the data of fish composition was taken from the fishing experiment. Fish samples were collected using a gill net with 2.5 inches of mesh size, $40 \times 50 \mathrm{~m}$, and operated for an hour with three replication times. The fish composition will be shown by percentage and its average catch $(\mathrm{kg})$. The fish samples were preserved with $10 \%$ formalin. Fish was identified by comparing morphology and meristic characters of the sample to reference books [6]. Water quality data were collected in each station [7]. Water sample analysis was done according to the standard 
method [8]. The secondary data were obtained from the related institution and previous studies.

\section{Results and Discussion}

\subsection{Fish Diversity}

During the study, it was identified 15 freshwater fishes. This result was more than the study in 2012 that found twelve species [4]. Fishing activities mainly occur in a few areas along the lake, but the higher diversity was in the south part of the lake. The identified fish could be categorized into endemic fish, introduced fish, and native fish. The abundance of each species was stated by rarely, frequently, and abundant. Table 1 shows the species and its abundance of Ayamaru Lake.

Table 1. The freshwater fish inhabited the Ayamaru Lake

\begin{tabular}{|c|c|c|c|c|c|}
\hline No & Local Name & Species Name & Common Name & Category & Abundance \\
\hline 1 & Mas & Cyprinus carpio (Linnaeus, 1758) & Common carp & Introduced & $* * *$ \\
\hline 2 & Gurame & Osphronemus gouramy (Lacepède, 1801) & Giant gourami & Introduced & $* * *$ \\
\hline 3 & Sepat & Trichogaster pectoralis (Regan, 1910) & $\begin{array}{l}\text { Snakeskin } \\
\text { gourami }\end{array}$ & Introduced & $* * *$ \\
\hline 4 & Gastor & Channa striata (Bloch, 1793) & $\begin{array}{l}\text { Striped } \\
\text { snakehead }\end{array}$ & Introduced & $* * *$ \\
\hline 5 & Nila & Oreocromis niloticus (Linnaeus, 1758) & Nile tilapia & Introduced & $* *$ \\
\hline 6 & Tet & Helostoma temminckii (Cuvier, 1829) & Kissing gourami & Introduced & $* *$ \\
\hline 7 & Betik & Anabas testudineus (Bloch, 1792) & Climbing perch & Introduced & $* *$ \\
\hline 8 & Atauwiyah & Cherax boesemani Lukhaup \& Pekny, 2008 & & Native & $* *$ \\
\hline 9 & Sekiak/Pelangi & $\begin{array}{l}\text { Melanotaenia boesemani (Allen \& } \\
\text { Cross, 1980) }\end{array}$ & $\begin{array}{l}\text { Boeseman's } \\
\text { rainbowfish }\end{array}$ & Endemic & $*$ \\
\hline 10 & $\begin{array}{l}\text { Beloso/Goby } \\
\text { Hoese }\end{array}$ & $\begin{array}{l}\text { Glossogobius hoesei (Allen \& Boeseman, } \\
\text { 1982) }\end{array}$ & Hoese's goby & Endemic & $*$ \\
\hline 11 & Pelangi & $\begin{array}{l}\text { Melanotaenia ajamaruensis (Allen \& Cross, } \\
\text { 1980) }\end{array}$ & $\begin{array}{l}\text { Ajamaru lakes } \\
\text { rainbowfish }\end{array}$ & Endemic & $*$ \\
\hline 12 & $\begin{array}{l}\text { Vogelcop mata } \\
\text { biru }\end{array}$ & $\begin{array}{l}\text { Pseudomugil reticulatus } \\
\text { (Allen \& Ivantsoff, 1986) }\end{array}$ & $\begin{array}{l}\text { Vogelkop blue- } \\
\text { eye }\end{array}$ & Endemic & $*$ \\
\hline 13 & Lele & Clarias batrachus (Linnaeus, 1758) & $\begin{array}{l}\text { Philippine } \\
\text { catfish }\end{array}$ & Introduced & $*$ \\
\hline 14 & Betutu & Oxyeleotris marmorata (Bleeker, 1852) & Marble goby & Native & $*$ \\
\hline 15 & $\begin{array}{l}\text { Tandan sirip } \\
\text { pendek/ } \\
\text { sembilang hitam }\end{array}$ & $\begin{array}{l}\text { Neosilurus brevidorsalis } \\
\text { (Günther, 1867) }\end{array}$ & Shortfin tandan & Native & $*$ \\
\hline
\end{tabular}

Based on survey results and interview with fishers, it is known that the fish in Ayamaru Lake were generally economically important. There were four fish with high abundance, which are both consumption and economical fish. Then, four species were frequently found. Three of them have a high economic value for consumption fish, and the rest were shrimp. The less commonly found were endemic fish, namely the Boeseman's rainbowfish, Ajamaru lakes rainbowfish, Vogelkop blue-eye, and Hoese's goby. Endemic fish were becoming difficult to find due to introduce predatory fish such as common carp and snakehead fish. Predatory fish will prey on the seeds or young endemic fish. These species were relatively abundant in non-permanent inundation areas.

The Cherax boesemani was found in this lake. It is a shrimp species from the Ayamaru Lakes, West Papua, Indonesia [9], and it is a native species [10]. Furthermore, [10] stated that Cherax boesemani could live in water with a $\mathrm{pH}$ of approximately 6.4 , a soft muddy bottom mostly covered with rich aquatic vegetation. The fish composition with the average catch during the fishing experiment in Ayamaru Lake is shown in Figure 2. 


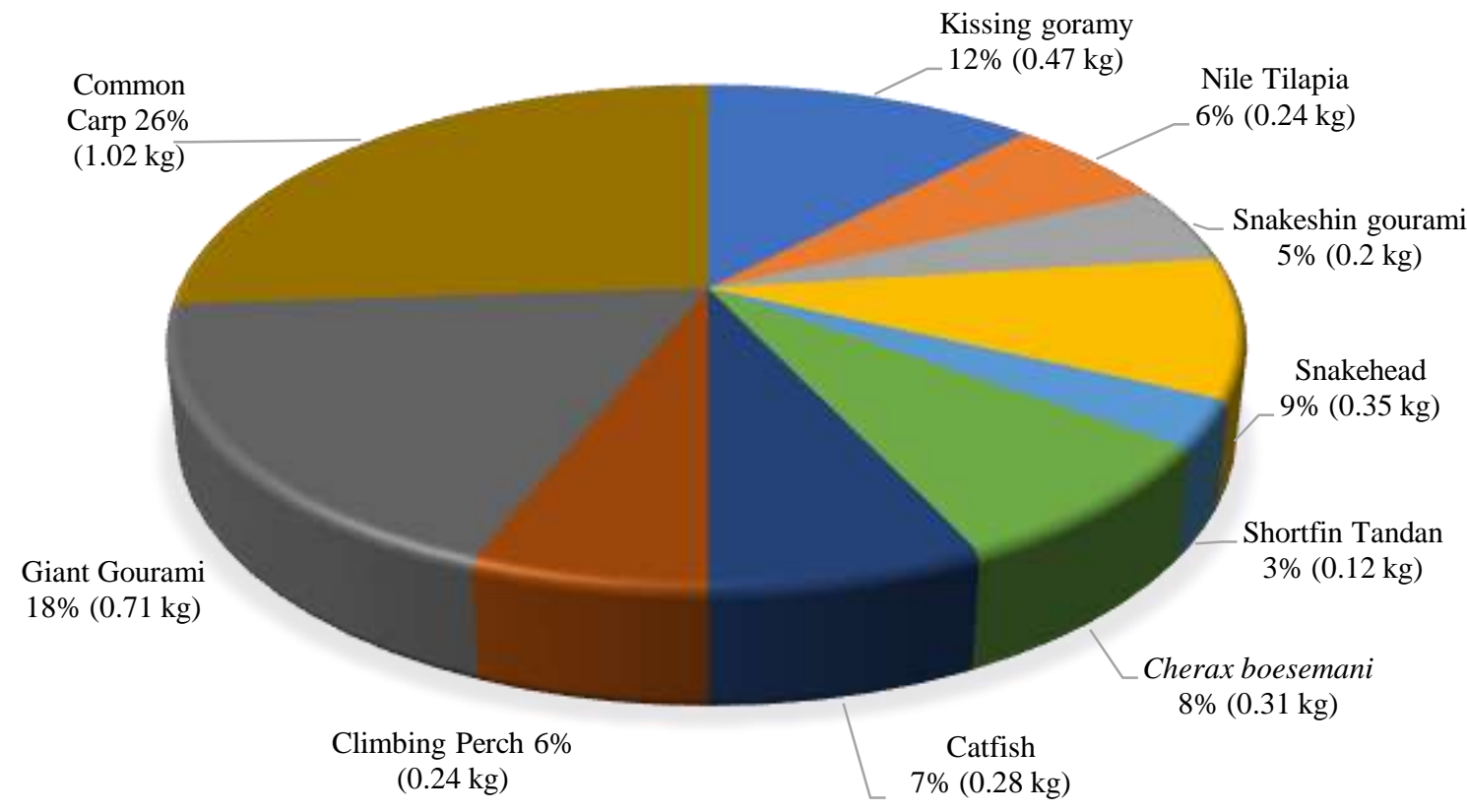

Figure 2. Fish caught composition in Ayamaru Lake during the fishing experiment.

Figure 2 shows ten fish species caught by fishers for consumption, dominated by common carp, giant gourami, and kiss gourami. The dominant species were classified as the white fish, which usually live in waters with a $\mathrm{pH}$ value of about 7 degrees. However, introduced fish such as snakeheads and catfish can also be inhabited in the lake. This condition showed when the water level was high, snakeheads and catfish prefer non-permanent inundation areas as their habitat. The Catfish, Clarias, and Anabantoids, with their auxiliary respiratory organs, can absorb low oxygen in swampy areas, which can tolerate low dissolved oxygen content of $0.05-0.10 \mathrm{mg} / \mathrm{L}$ [6][11].

\subsection{Water Quality}

Some water lake parameters indicated that it was still within the tolerance range for the aquatic organisms' life, including fish (Figure 3). Water temperature was between $24.0-31.7^{\circ} \mathrm{C}$, with an average of $26.59^{\circ} \mathrm{C}$. Water temperature will decrease based on the depth (surface, transparency, and bottom).
The dissolved oxygen content range was between 2.48-9.91 mg per liter or on average of 6.08 $\mathrm{mg} / \mathrm{liter}$. Compared with Tempe Lake [12], the dissolved oxygen was around 1.9-10.4 mg/l. As well temperature, the oxygen will decrease depending on the depth. The dissolved oxygen in Ayamaru Lake showed a very drastic decrease, and it was related with the average transparency limit area of approximately 1 $\mathrm{mg} / \mathrm{l}$ with average transparency of 0.6 meters. The lake's transparency was in ranges from 0.9 to 13.5 meters or an average of $5.7 \mathrm{~m}$.

This lake also holds potential as tourism objects in Maybrat Regency, such as Ayamaru Lake in the Ayamaru District and Uter Lake in Aitinyo District. Lake Ayamaru is about 2.500 ha, including the type of eutrophic series whose productivity depends on the nutrients it receives and regional irrigation at geological age. The depth of abundance of plankton is less due to high sedimentation rates resulting in thin light penetration. Fish that can inhabit Ayamaru Lake, categorized as flood exposure ecosystems, are the specifically adapted fish [6]. 


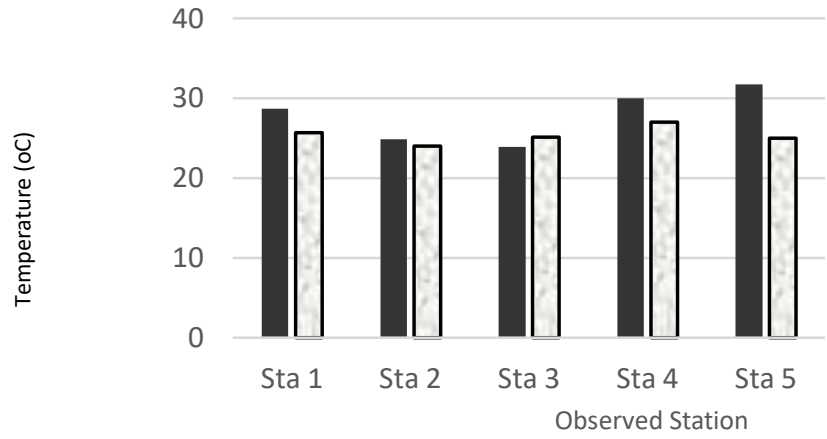

- March aJuly

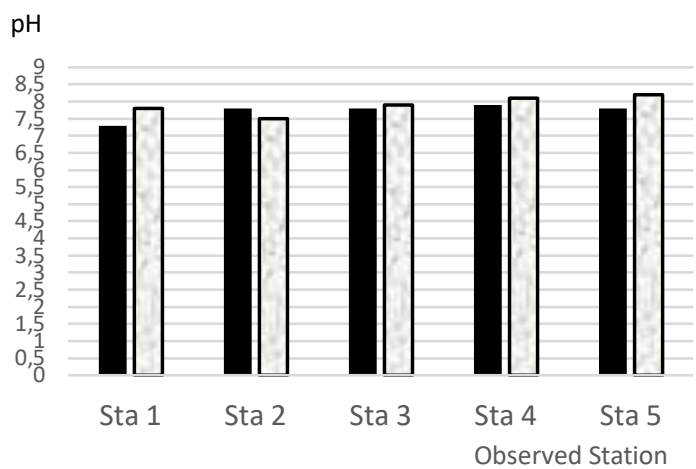

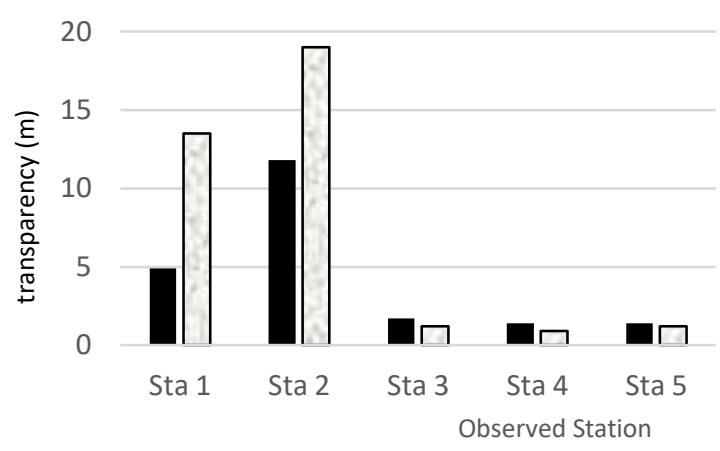

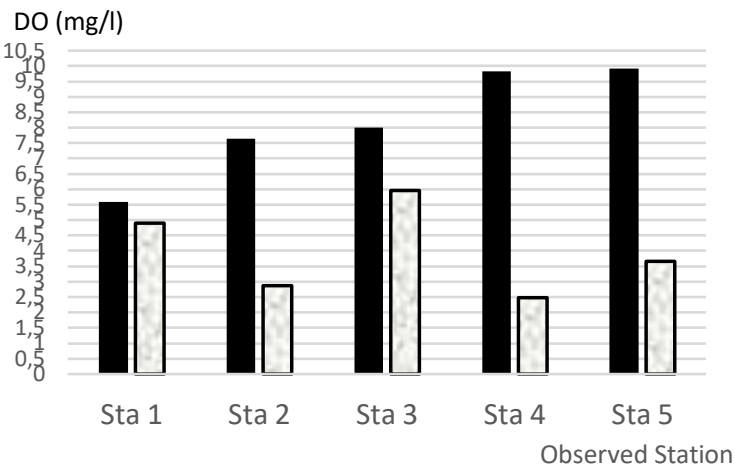

Observed Station

Figure 3. Temperature, transparency, $\mathrm{pH}$ and dissolved oxygen of Ayamaru Lake

Judging from the nutrient content and condition of the phytoplankton community and the rate of primary productivity, the waters of Lake Ayamaru are estimated to be in a eutrophic state. It needs the efforts to control water fertility, primarily through developing a good sanitation system in residential areas around the lake [4]. The range of $\mathrm{pH}$ was 7.5-8.2 or an average of 7.81. Generally, lake waters have $\mathrm{pH}$ value above seven or an average of 8 . The $\mathrm{pH}$ of Ayamaru Lake was relatively the same as some lakes in Indonesia, such as Kerinci Lake (7.1 - 8.2) [13] and Tempe Lake (6.6-8.6) [12]. In 2012, the Ayamaru lake was unique water, that as the karst area, the $\mathrm{pH}$ tended to alkaline $(\mathrm{pH}>7)$ with a high hardness level [14]. The $\mathrm{pH}$ in Ayamaru Lake is still ideal for supporting the life and breeding of aquatic organisms following [15]; the $\mathrm{pH}$ range at 6-9 is ideal for fisheries production. Based on Regulation of the Minister of Health, Republic of Indonesia No 32/2017 mentioned for water quality standards of chemical parameters [16] for water for sanitary hygiene purposes, the $\mathrm{pH}$ of water is ranged in 6.5- 8.5. This lake is a source of daily water for the residents who live around the lake.

\subsection{Fisheries Management of Ayamaru Lake}

Ayamaru Lake has an ecological function as the habitat, the control of groundwater, and microclimate. The reduced area of forest cover in the upper part of Ayamaru Lake's catchment area caused significant water level differences between the rainy season and the dry season. In the dry season, the water level becomes lower. Since 2005, the Ayamaru Lake has receded into $50 \mathrm{~m}$, some even dried up and overgrown with grass. It was almost the same as Turkana Lake that it could reduce into two small pools. The lake's reduced water levels will have a damaging impact on people's environment and livelihoods around Lake Turkana [17]. The fluctuation of water level could affect the water quality [18].

Ayamaru Lake also has a function for socioeconomical, i.e., tourism destination and fishery activities. The livelihood of the people surrounding the lake depends on the lake's condition. The rural people earn a living from capture and fish culture activity. Some fish cultures applied floating net cages. While the capture fishery activities were practiced using the most common fishing gear, i.e., spears, harpoon, and gillnet. The fish target to send the market was the big fish that were captured by spears or harpoon. While the gillnet will catch the escaped fish from the cultured area.

Since Ayamaru Lake has functioned as an ecological buffer and economical as the income source, it should be managed harmoniously. The management of Ayamaru Lake must be done comprehensively by sustaining the endemic species. The rainbowfish species, as the endemic species, have restricted distributions and are confined to specific habitats. These fish are highly vulnerable to environmental disturbance, overharvesting, and anthropogenic activities. The development of ecotourism affected the Ayamaru Lake waters. Forest 
clearance has increased channel obstructions by sediments and led to the lake's partial drying [5].

The simultaneous over-catching of the endemic Boeseman's Rainbowfish for ornamental fish with high price drove this species to the verge of extinction. Efforts to restore the rainbow fish population need to be made. To reduce the threat to the presence of endemic fish in the lake, it needs to control the release of introduced species that have a chance to be predator fish. Besides, it is also suggested to limit the development of snakehead fish population by intensive fishing.

\section{Conclusion}

During the study, 15 fish species inhabited Ayamaru Lake, consisted of endemic, native, and introduced species. The water quality was quite good for supporting the fish life. To reduce the threat to the presence of endemic fish in the lake, it needs to regulate the release of introduced species by the community, and control the escaped fish from the culture area.

\section{Acknowledgement}

The study entitled "Fish Diversity and Water Quality of Ayamaru Lake, West Papua" was funded by the Ministry of Marine Affairs and Fisheries Republic of Indonesia throughout the Research Institute for Inland Fisheries and Extension 2019. The authors acknowledge the assistance of Ms. Diana Luspa in proof-reading this article. We also thank the technicians (Sidarta Gautama, Gatot Subroto, Armun, and Yenni S. Mulyani) for helping during the field survey, laboratory work, and map preparation. Taufiq Hidayah and Marson are the main contributors to this paper. The authors gratefully acknowledge Dr. Dina Muthmainnah for actively supervising on writing this manuscript.

\section{References}

[1] Ministry of Environment of Republic Indonesia, "Indonesian Lake Management: The Indonesian Movement for Lakes Ecosystem Conservation and Rehabilitation," Jakarta: Ministry of Environment Press. 2014, pp. 31.

[2] D. Muthmainnah, S. Makmur, A. H. Rais, S. Sawestri, F. Supriyadi, and K. Fatah, The Features of Inland Fisheries in Southeast Asia. Ed: N. N. Wiadnyana, L. Adrianto, V. T. Sulit, A. Wibowo. Bogor: IPB Press, 2019.

[3] E. S. Kartamihardja, K. Purnomo, and C. Umar, "The freshwater fish resources in Indonesianeglected," (in indonesian) Indonesian Fisheries Policy Journal, vol. 1 no 1, pp. 1-15. May. 2009.
[4] T. Chrismadha, Lukman, and M. Fakhrudin, "The environment of Ayamaru Lake, West Papua,"(in Indonesian) Proceeding of $7^{\text {th }}$ Limnology National Seminar. Pp. 608-626. 2014.

[5] M. F. I. Nugraha, L. Pouyaud, O. Carman, U. Widyastuti, Z. Junior, M. Kadarusman, and J. C. Avarre, "Genetic diversity of Boeseman's Rainbowfish (Melanotaenia boesemani) reared in Indonesian farms compared to endangered natural populations," Tropical Conservation Science. vol. 8 no. 3, pp. 796-812. Available online: www.tropicalconservationscience.org

[6] M. Kottelat, A. J. Whitten, S. N. Kartikasari, and S. Wirjoatmojo, "Freshwater Fishes of Western Indonesia and Sulawesi," Periplus Edition-EMDI Project. Jakarta. 1993.

[7] R. A. Cooper, and A. J. Weekes, Data Models Statistical Analysis. Barnes and Noble Books. New Jersey. 1983. Pp. 364.

[8] APHA. 1981. Standart Method for the Examination of Water and Wastewater. $15^{\text {th }}$ Edition. Washington DC: American Public Health Association. p. 1134 .

[9] U.S. Fish and Wildlife Service. 2017. Cherax boesemani (a crayfish, no common name). Ecological Risk Screening Summary. Revised Edition. https://www.fws.gov/fisheries/ ANS/erss/uncertainrisk/

ERSS_Cherax_boesemani_final_December_20 17.pdf

[10] C. Lukhaup, and R. Pekny, "Cherax (Astaconephrops) boesemani, a new species of crayfish (Crustacea: Decapoda: Parastacidae) from the centre of the Vogelkop Peninsula in Irian Jaya (West New Guinea), Indonesia,". Zoologische Mededelingen Leiden vol. 82, no 7, pp. 331- 340. 2006.

[11] A. S. Halls, and M. Johns, "Assessment of the vulnerability of the Mekong Delta Pangasius catfish industry to development and climate change in the Lower Mekong Basin," Report prepared for the Sustainable Fisheries Partnership, Jan 2013, pp. 95

[12] R. Dina, E. Harsono, G. Wahyudewantoro, Lukman, R. Kurniawan, A. Waluyo, J. Sudarso, and M. R. Widoretno, "Fish distribution in the difference inundation area of Tempe Lake, South Sulawesi,"(in Indonesian) Oceanology and Limnology in Indonesia. vol. 5, no. 3, pp. 183-197. 2020. doi: 10.14203/oldi.2020. v5i3.334.

[13] Samuel, N. K. Suryati, D. Muthmainnah, S. Sawestri, and M. Fachmi, "Kerinci Lake: Utilization Status and Its Management Option,"(in Indonesian) AMaFRaD Press. 2016. ISBN 978-602-8380-0-2. 
[14] I. S. Sulistyorini, M. Edwin, and A. S. Arung, "Quality Analisys of Springs in Karangan and Kaliorang Districts, East Kutai," (in Indonesian) Journal of Tropical Forest. vol. 4 no. 1 ISSN 2337-7771. E-ISSN 2337-7992.

[15] C. E. Boyd, "Water Quality in Warmwater Fishponds," Auburn University, Department of Fisheries and Applied Aquaculture. First Edition, Alabama USA. 1979. pp. 359.

[16] Ministry of Health Republic of Indonesia. "Regulation of Minister of Ministry of Health Republic of Indonesia No 32/2017:
Environmental Health Quality Standards. (in Indonesian). 1979

[17] P. E. Lokoel, "There is no time left. Climate change, environmental threats and human rights in Turkana Country, Kenya," 1979. [online]. Available at https://www.hrw. org/report/2015/10/15/there-notime-

left/climate-change-environmental-threats-andhuman-rights-turkana\#page.

[18] W. Hamza, "The Nile fishes and fisheries. In O. Grillo, ed. Biodiversity the dynamic balance of the planet,". Intech. 2014. doi: 10.5772/57381. 